\title{
PLANT ESSENTIAL OILS FOR ENVIRONMENT-FRIENDLY PROTECTION OF WOOD OBJECTS AGAINST FUNGI
}

\author{
Mohsen Bahmani ${ }^{1, \diamond}$, Olaf Schmidt ${ }^{2}$
}

\author{
In memoriam of Dr. Thomas C. MANNES
}

\begin{abstract}
The study was aimed at testing environmental-friendly plant essential oils for their protecting efficiency of valuable woods against colonization by mould and wood-decay fungi. Sixteen essential oils were applied to Fagus orientalis and Pinus taeda wood samples by vacuum impregnation and infected with Aspergillus niger, Penicillium commune (moulds), Coniophora puteana (brown rot), Trametes versicolor (white rot), Chaetomium globosum (soft rot) and natural infection by airborne spores. Lavender oil, lemon grass oil and thyme oil were the most effective oils against all fungi tested.
\end{abstract}

Keywords: Beech, moulds, pine, wood decay fungi, wood protection.

\section{INTRODUCTION}

Old woods such as archaeological woods, woods in historical buildings, works of art, antique furniture are important parts of the cultural heritage that gives us valuable information about the past. Due to the high historic potential they must be protected against damages. A large part of historic wood is found inside such as carvings, altarpieces in churches, mosques and museums (Blanchette 2000, Cojocariu and Tanase 2010, Ortiz et al. 2014). Historic wooden structures may be attacked by various degradation agents (Blanchette 2000). Among them, the infection and subsequent growth of moulds and other fungi may cause considerable damages (Sterflinger 2010). Fungal damages are often caused by high level of ascension humidity, lack of ventilation and intermittent warming and condensation. A method to protect valuable woods may be the use of plant essential oils. Essential oils have benefits such as they can provide safe and environmentally friendly preservatives. They are effective against bacteria (Burt 2004, Wong et al. 2008), fungi (Carlton et al. 1992, Mahmoud 1994, Voda et al. 2003, Wang et al. 2005, Singh and Singh 2012, Boulogne et al. 2012, Fidah 2016) and insects (Isman et al. 2011, Fatima and Morrell 2015). Some studies were done on the efficacy of essential oils against moulds (Voda et al. 2003, Yang and Clausen 2006, Pánek et al. 2014). Caccioni et al. (1998) tested mould (Penicillium species) inhibition by citrus essential oils measuring the growth in oil-containing nutrient broth. Su et al. (2006) obtained growth inhibition of moulds and wood-decay fungi by Eucalyptus citriodora essential oil dispersed in agar. Viuda-Martos et al. (2008) showed antimould activity of lemon, mandarin, grapefruit and orange essential oils in agar. Yang and Clausen (2007) obtained mould inhibition on pine stakes dipped in geranium and thyme oil. Zyani et al. (2011) found mould inhibition by oils of Origanum compactum, Eugenia caryophyllata and Ocimum basilicaum using the disc diffusion method and minimum inhibitory concentration in agar dilution test. Pánek et al. (2014) evaluated ten essential oils against wood-destroying fungi and moulds. They stated that essential oils containing phenol components such as carvacrol, eugenol, thymol and cisisoasarol trimethyleter have the most effect for beech wood protection against fungi in interior conditions. Experiments with woods impregnated with plant extracts are rare. Goktas et al. (2010) showed some protection of beech and pine wood against Oligoporus placenta (brown rot) and Trametes versicolor (white rot) when the

\footnotetext{
${ }^{1}$ Department of Natural Resources and Earth Science, Shahrekord University, Shahrekord, Iran.

${ }^{2}$ Wood Biology, University of Hamburg, Leuschnerstr. 91, 21031 Hamburg, Germany.

"Corresponding author: mohsen.bahmani@nres.sku.ac.ir

Received: 01.04.2017 Accepted: 22.01.2018
} 
samples were treated with extracts of Muscari neglectum and Gynandrinum sysyrinchium. Chittenden and Singh (2013) monitored antifungal activity of essential oils against wood degrading fungi and concluded that eugenol and cinnamaldehyde are applicable for protection of timber when not exposed to wet conditions. Sailer (2001) obtained lower mass loss in cultures with T. versicolor and Coniophora puteana (brown rot) when the wood samples of pine, larch, beech and oak were impregnated with linseed and hempseed oil. Our study evaluates the efficacy of 16 plant essential oils against moulds and wood decay fungi using impregnated beech and pine wood samples to test their possible application for protecting valuable wood objects.

\section{MATERIAL AND METHODS}

The wood samples derived from trees of Oriental beech (Fagus orientalis Lipsky) and Loblolly pine (Pinus taeda L.) felled in September 2016 in the Kheyroud-Kenar forests, Iran. The sample size of $30 \times 30 \times 51 \mathrm{~mm}$ was used to obtain great radial surfaces for intense impregnation with oils and for subsequent sample placement in Petri dishes. The samples were numbered, dried at $103{ }^{\circ} \mathrm{C}$, weighed for dry matter determination, grouped in large glass dishes according to the planned oil treatments and autoclaved for $15 \mathrm{~min}$ at $121{ }^{\circ} \mathrm{C}$. This basic sterilization was thought to be necessary to reduce subsequent mould infections in cultures with the slowly growing basidiomycetes.

As essential oils, 16 oils (Table 2) were purchased from several German manufacturers specialized in those products. Oils were obtained as $100 \%$ concentrations to avoid unknown and diverse dilution chemicals. For wood impregnation, $10 \%$ concentrations were made by diluting with native olive oil. Impregnation was done in a desiccator with 15 min initial vacuum by a pump, oil addition via a funnel in the desiccator lid, followed by $15 \mathrm{~min}$ duration for oil uptake. There was no sample sterilization after impregnation to avoid oil removal from the treated samples due to pressure variations in the autoclave. However, the desiccator and all other glasses for impregnation had been disinfected in advance to minimize wood infections from the laboratory. Oil uptake was determined by weighing some samples after impregnation. The impregnated wood samples were lightly touched on clean filter papers to remove oil from the surfaces and immediately placed on fungal mycelia grown on $2 \%$ malt-1,5\% agar (Oxoid) in Petri dishes.

Table 1. Fungi used.

\begin{tabular}{|l|l|l|l|}
\hline \multicolumn{1}{|c|}{ Species } & \multicolumn{1}{c|}{ Wood damage } & \multicolumn{1}{c|}{ Coding } & \multicolumn{1}{c|}{ Origin } \\
\hline Aspergillus niger & Moulding & 15 & Soil of pot flower \\
\hline Penicillium commune & “ & 311 & Chinese bamboo \\
\hline Natural infection & “ & & Airborne spores \\
\hline Coniophora puteana & Brown rot & 167 & Fruiting body, Hamburg \\
\hline Trametes versicolor & White rot & CTBA 863 & France \\
\hline Chaetomium globosum & Soft rot & 10, ATCC 44753 & \\
\hline
\end{tabular}

Table 1 lists the used fungi with their coding/origin kept in the laboratory strain collection of the second author. Each 2 (for moulds) or 3 (for decay fungi) samples per oil treatment were placed on the fungal mycelia grown in Petri dishes. Natural infection by the surrounding laboratory air was performed by storing the open dishes with the samples for 1 hour. Thereafter, all dishes were sealed with Parafilm against drying. Untreated samples as well as samples impregnated with $100 \%$ olive oil were used as controls. Incubation was done at room temperature for 8 to 10 weeks and growth was weekly controlled. The closed mould dishes were several times roughly shaken during incubation to induce further sample infection by spores from the surrounding basal mycelial colony, because moulds spread mainly by their spores and lesser by mycelial growth (Schmidt 2006). After incubation, samples were cleaned from superficial mycelium, weighed for wet wood determination, again dried at 103 ${ }^{\circ} \mathrm{C}$ and finally weighed for mass loss determination. The used method investigates the colonization/ infection of wood by fungi and not a subsequent wood decay inhibited by the low wood moisture content. European or American test standards were not applied as the above technique is successfully used for several years in the laboratory of the second author. 


\section{RESULTS AND DISCUSSION}

\section{Efficacy of essential oils against mould fungi}

The tested oils differed considerably in their efficacy against moulds. Figure 1 shows as an example beech wood sample incubated with Aspergillus niger. The sample with olive oil (left) was fully overgrown, fennel oil yielded medium growth (centre) and lemon grass oil (right) inhibited the mould totally.

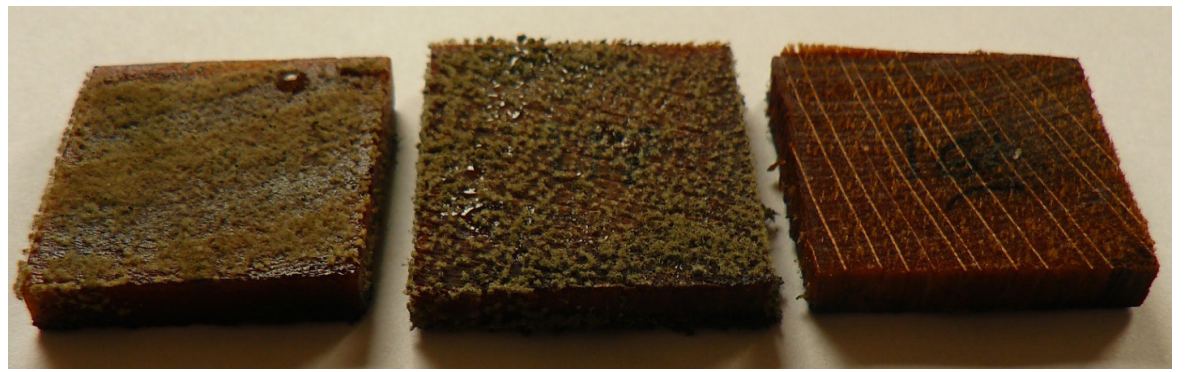

Figure 1. Beech wood samples impregnated with olive oil (left), fennel oil (centre) and lemon grass oil (right) incubated with Aspergillus niger.

Table 2. Growth of mould fungi on oil-impregnated Fagus orientalis wood samples.

\begin{tabular}{|c|c|c|c|c|c|c|c|c|c|}
\hline \multirow[b]{2}{*}{ Oil (Plant origin) } & \multicolumn{3}{|c|}{ Aspergillus nige } & \multicolumn{3}{|c|}{ Penicillnum camunave } & \multicolumn{3}{|c|}{ Natural infection } \\
\hline & \multicolumn{9}{|c|}{ Grouth after weels } \\
\hline & 2 & 4 & 10 & 2 & 4 & 10 & 2 & 4 & 10 \\
\hline Control & 0 & 2 & 3 & 0 & 2 & 3 & 2 & 3 & 3 \\
\hline Control Olive & 0 & 2 & 3 & 0 & 1 & 3 (thin) & 1 & 3 & 3 \\
\hline \multirow{2}{*}{$\begin{array}{l}\text { Ajowan } \\
\text { Trachyspenum copticum) } \\
\text { Berganot (Cirus } x \text { liman) }\end{array}$} & 0 & 0 & 1 & 0 & 1 & $2-3^{\circ}$ & 0 & 0 & $\operatorname{margin}$ \\
\hline & 0 & 3 & 3 & 0 & 0 & 0 & 0 & 0 & 0 \\
\hline Cedar wood (Juiperu mexicava) & 0 & 3 & 3 & 0 & $\frac{1-}{2}$ & $1-3$ & 0 & 0 & $\operatorname{margin}$ \\
\hline \multirow{3}{*}{$\begin{array}{l}\text { Chamomile } \\
\text { (Matricariachamamilia) } \\
\text { Eucalyptus } \\
\text { (Eucalypus gioboius) } \\
\text { Fennel } \\
\text { (Foeniculum vigure) }\end{array}$} & 0 & 3 & 3 & 0 & 0 & 2 & 0 & 0 & 0 \\
\hline & 0 & 3 & 3 & 0 & 0 & 0 & 0 & 0 & 0 \\
\hline & 0 & $\begin{array}{l}2 \\
5\end{array}$ & $2-3$ & 0 & 0 & 1 (thin) & 0 & 0 & margin \\
\hline \multirow{4}{*}{ 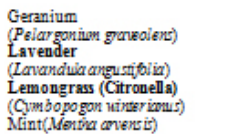 } & 0 & 1 & 2 & 0 & 0 & traces & 0 & 0 & 0 \\
\hline & 0 & 0 & traces & 0 & 0 & 0 & 0 & 0 & margin \\
\hline & 0 & 0 & 0 & 0 & 0 & margin & 0 & 0 & 0 \\
\hline & 0 & 2 & 2 (thin) & 0 & 0 & 0 & 0 & 0 & margin \\
\hline Neem (Meleacrorialincrita) & 0 & 0 & 3 & 0 & 0 & traces & 0 & 0 & 3 (thin) \\
\hline \multirow{5}{*}{ 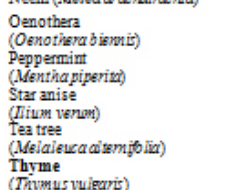 } & $1-2$ & 2 & 3 (thin) & 0 & 0 & traces & 0 & 0 & traces \\
\hline & 0 & 1 & 3 (thin) & 0 & 0 & traces & 0 & 0 & margin \\
\hline & 0 & 1 & 3 (thin) & 0 & 0 & 0 & 0 & 0 & 0 \\
\hline & 0 & 1 & 2 (thin) & 0 & 0 & traces & 0 & 0 & 0 \\
\hline & 0 & 0 & 0 & 0 & 0 & traces & 0 & 0 & 0 \\
\hline
\end{tabular}

0 - no growth on sample surface; 1 - about 1/3 of sample surface overgrown; 2 - about half surface overgrown; 3 - whole surface overgrown; margin - sample sides overgrown; *- growth differs among samples.

Table 2 summarizes the results for the beech wood samples. The control wood samples were fully overgrown by moulds within 4 to 10 weeks of incubation. Growth became obvious by thin hyphae on the upper sample area followed by the development of new conidial structures (conidiophores with conidia). If this growth had happened by mycelium reaching the upper sample area from the fungus colony on the agar and/or by flying spores within the Petri dish could not be distinguished. Remarkable is the slight decrease of infection intensity by the olive oil.

Considerable differences were found among the 16 oils tested. Most oils yielded only some mould inhibition. However, the oils from lavender, lemon grass and thyme (fat) showed sufficient inhibition 
on both moulds and the natural infection by airborne spores, allowing only some growth on the sample side area within 10 weeks of incubation. Thyme oil was already shown by Yang and Clausen (2007) to inhibit the growth of A. niger and Penicillium chrysogenum).

Table 3. Growth of mould fungi on oil-impregnated Pinus taeda wood samples.

\begin{tabular}{|c|c|c|c|c|c|c|c|c|c|}
\hline \multirow{3}{*}{ Oil } & \multicolumn{3}{|c|}{ Aspergillus niger } & \multicolumn{3}{|c|}{ Penicillium commure } & \multicolumn{3}{|c|}{ Natural infection } \\
\hline & \multicolumn{9}{|c|}{ Grouth after weels } \\
\hline & 2 & 4 & 8 & 2 & 4 & 8 & 2 & 4 & 8 \\
\hline Control & 0 & 2 & 3 & 0 & 2 & 3 & 2 & 3 & 3 \\
\hline Control Olive & 0 & 2 & 3 & 0 & 1 & 3 (thin) & 1 & 3 & 3 \\
\hline Ajowan & 0 & 0 & 1 & 0 & 1 & $2-3$ & & 0 & margin \\
\hline Berganot & 0 & 3 & 3 & 0 & 0 & 0 & 0 & 0 & 0 \\
\hline Cedar wood & 0 & 3 & 3 & 0 & $1-2$ & $1-3$ & 0 & 0 & margin \\
\hline Chamomile & 0 & 3 & 3 & 0 & 0 & 2 & 0 & 0 & 0 \\
\hline Eucalyptus & 0 & 3 & 3 & 0 & 0 & 0 & 0 & 0 & 0 \\
\hline Fennel & 0 & $2+3$ & $2-3$ & 0 & 0 & 1 & 0 & 0 & margin \\
\hline Geranium & 0 & 1 & 2 & 0 & 0 & traces & 0 & 0 & 0 \\
\hline Lavender & 0 & 0 & traces & 0 & 0 & 0 & 0 & 0 & margin \\
\hline Lemongrass & 0 & 0 & 0 & 0 & 0 & margin & 0 & 0 & 0 \\
\hline Mint & 0 & 2 & 2 (thin) & 0 & 0 & 0 & 0 & 0 & margin \\
\hline & 0 & 0 & 3 & 0 & 0 & traces & 0 & 0 & 3 (thin) \\
\hline Oenothera & $\begin{array}{l}1 \\
2\end{array}$ & 2 & 3 (thin) & 0 & 0 & traces & 0 & 0 & Traces \\
\hline Peppernint & 0 & 1 & $3(\operatorname{thin})$ & 0 & 0 & traces & 0 & margin & margin \\
\hline Star anise & 0 & 1 & 3 (thin) & 0 & 0 & 0 & 0 & 0 & 0 \\
\hline Tea tree & 0 & 1 & $1-2$ (thin) & 0 & 0 & traces & 0 & 0 & 0 \\
\hline Thyme & 0 & 0 & 0 & 0 & 0 & traces & 0 & 0 & 0 \\
\hline
\end{tabular}

The results for pine wood are summarized in Table 3. As with beech wood, the oils from lavender, lemon grass and thyme were the most effective oils for pine wood protection from moulds. This result is not astonishing because the characteristic feature of mould fungi on wood is their growth restricted to the surfaces and outermost wood regions (Schmidt 2006). The substrate underneath, in this case beech or pine wood, has no influence because these fungi do not feed from the woody cell wall.

Remarkable is the formation of an inhibition zone in the agar by geranium oil. Figure 2 shows such zone spreading from the treated wood sample towards the neighbouring mould colonies. If this was due to oil diffusion through the agar or by vapour remains unclear. Zyani et al. (2011) showed that some oil constituents are active as vapour.

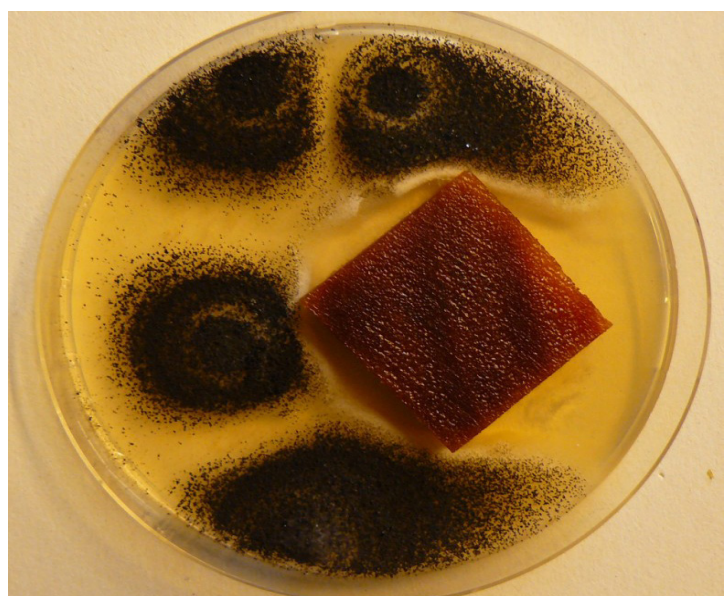

Figure 2. Inhibition zone by geranium oil against neighbouring mould growth. 


\section{Efficacy of essential oils against wood decay fungi}

Table 4 shows the influence of the essential oils in impregnated beech wood samples on wooddecay fungi. The controls without any oil were totally overgrown by mycelium already after 2 weeks of incubation. However, already the olive oil controls showed a slight to strong growth inhibition particularly with the brown-rot species Coniophora puteana. Among the 16 oils tested, like against the deuteromycetes (Table 2 and Table 3), the oils from lavender, lemon grass and thyme were effective in view of growth inhibition; additionally ajowan oil inhibited the three rot fungi.

Table 4. Growth of wood-decay fungi on oil-impregnated Fagus orientalis wood samples.

\begin{tabular}{|c|c|c|c|c|c|c|c|c|}
\hline \multirow{3}{*}{ Oil } & \multirow{2}{*}{\multicolumn{8}{|c|}{$\begin{array}{c}\text { Tramets vensiowler } \\
\text { Grouth after weels }\end{array}$}} \\
\hline & & & & & & & & \\
\hline & 2 & 4 & 10 & 2 & 4 & 10 & 4 & 10 \\
\hline Control & 3 & 3 & 3 & 3 & 3 & 3 & 3 & 3 \\
\hline Olive & 1 & 1 & $1-2$ & 2 (thin) & 2 & 3 & 3 & 3 \\
\hline Ajowan & 0 & 0 & 0 & 0 & 0 & margin & 0 & 0 \\
\hline Bergamot & $2-3$ & $2-3$ & 3 & 2 & 2 & $2-3$ & 0 & margin \\
\hline Cedar wood & 2 & 2 & 3 & 0 & 1 & 3 & 1 & 3 (thin) \\
\hline Chamomile & 3 & 3 & 3 & 1 & 2 & $3($ thin $)$ & 3 & 3 \\
\hline Eucalyptas & 3 (thin) & 3 (thin) & 3 & 0 & 1 & $2-3$ (thin) & 0 & 0 \\
\hline Fennel & 0 & 0 & 0 & 1 & 1 & $1-2$ (thin) & 0 & traces \\
\hline Geranium & 1 & 2 & $2-3$ & 0 & 0 & 1 (thin) & 0 & 0 \\
\hline Lavender & 0 & 0 & margin & 0 & 0 & traces & 0 & 0 \\
\hline Lemongrass & 0 & 0 & 0 & 0 & 0 & 0 & 0 & 0 \\
\hline Mint & 1 & $2-3$ & 3 & 0 & 1 & 1 (thin) & 0 & 0 \\
\hline \multirow[t]{2}{*}{$\begin{array}{l}\text { Neem } \\
\text { Oenothera }\end{array}$} & 3 & 3 & 3 & 2 (thin) & $\frac{2}{2}$ & 2 & 3 & 3 \\
\hline & 3 & 3 & 3 & 2 (thin) & th & 2 (thin) & 3 & 3 \\
\hline Peppermint & 0 & 0 & $1-2$ & 2 & 2 & $2-3$ & 0 & margin \\
\hline Star anise & 0 & 1 & 1 & 0 & 0 & traces & 0 & $\operatorname{margin}$ \\
\hline Tea tree & 0 & traces & $1-3$ & 0 & 1 & 2 (thin) & 0 & $0-1$ \\
\hline Thyme & 0 & 0 & traces & 0 & 0 & 0 & 0 & 0 \\
\hline
\end{tabular}

Table 5 shows the results obtained for wood-decay fungi and pine wood. Effective oils to protect the softwood derived from ajowan, geranium, lavender, lemon grass and thyme.

Most plant essential oils contain many constituents. Lavender oil and tea tree oil, for example, consist of over 100 active compounds. Su et al. (2006) identified 67 compounds from the essential oil of Eucalyptus grandis. Because quite different oils inhibited the fungi tested it can be assumed that several constituents were effective. Thymol is known as a strong antimicrobial agent. However, to correlate the antifungal activity to a single constituent or to classes of compounds is difficult. The various components of any oil may act sinergistically (Caccioni et al. 1998) while several compounds may have even a stimulating action on fungi, as shown by French (1985) for spore germination. Various possible action mechanisms by which fungal growth may be reduced or inhibited have been proposed (Viuda-Martos et al. 2008) such as effects on the functionality and structure of cell membranes, changes in cell structure, inhibition of respiration, and interactions with enzymes.

Table 5. Growth of wood-decay fungi on oil-impregnated Pinus taeda wood samples.

\begin{tabular}{lllc|c} 
Control & 2 & 4 & 8 & $z$ \\
Control Olive & 3 & 3 & 3 & 3 \\
Ajowan & 3 & 3 & 3 & 3 (thin) \\
Bergamot & 0 & 0 & margin & 0 \\
& 1 & $1-$ & $1-2$ & $0-1$ \\
Cedar wood & 2 & 1 & 3 & 2 (thin) \\
Chamomile & 2 & 2 & 3 (thin) & 2 \\
Eucalyptus & 0 & 0 & 0 & 0 \\
Fennel & 0 & $1-$ & $1-3$ & 0 \\
Geranium & 0 & 0 & margin & 0 \\
Lavender & 0 & 0 & 0 & 0 \\
Lemongrass & 0 & 0 & 0 & 0 \\
Mint & 1 & 2 & $2-3$ & $0-1$ \\
& 3 & & & \\
Neem & (th & 3 & 3 & 2 (thin) \\
& in) & & & \\
Oenothera & $2-$ & 3 & 3 & 2 \\
& 3 & & & 0 \\
Peppermint & 1 & 1 & 1 & 0 \\
Star anise & & & &
\end{tabular}

\begin{tabular}{ll|ccc}
4 & 8 & $\mathbf{2}$ & $\mathbf{4}$ & $\mathbf{8}$ \\
3 & 3 & 3 & 3 & 3 \\
3 & 3 & 3 (thin) & 3 & 3 \\
0 & 0 & 0 & 0 & 0 \\
0 & 1 & 0 & 1 & 1 \\
$\mathbf{1}$ & 1 & & & $1-3$ \\
3 & 3 & 0 & margin & 1 (thin) \\
2 & 3 (thin) & 0 & $1-2$ & $0-3$ (thin) \\
0 & 2 (thin) & 0 & 0 & 0 \\
2 & 2 & 0 & 0 & 0 \\
0 & 0 & 0 & 0 & 0 \\
0 & 0 & 0 & 0 & margin \\
0 & 0 & 0 & 0 & 0 \\
0 & $0-2$ (thin) & 0 & 0 & margin \\
1 & & & & \\
2 & 2 & 0 & $1-2$ & $2-3$ (thin) \\
2 & & & & \\
3 & 3 & 0 & $1-3$ & 3 \\
0 & margin & 0 & 0 & 0 \\
1 & & & &
\end{tabular}


The weight measurements after incubation (wet weight) indicated that most or even all oil introduced into the wood sample by the impregnation procedure was still present in the samples. Subsequent drying at $103{ }^{\circ} \mathrm{C}$ and weighing for mass loss determination did not yield any usable result because the oils resist this temperature. Reasons for the missing mass loss may be: The wood samples with open cells (fibres or tracheids) at both sample surfaces could be intensively impregnated with oils due to their great radial areas and small height. Oil uptake was about $560 \mathrm{~kg}$ oil (=56 kg essential oil) per $\mathrm{m}^{3}$ beech wood and about $620(62) \mathrm{kg} / \mathrm{m}^{3}$ pine wood. Typical of basidiomycetous brown- and white-rot fungi is their growth within the lumina of wood cells and excreting from there the enzymes and free radicals for cell wall degradation into the walls; soft-rot fungi (type I) such as Chaetomium globosum initially also invade the cell lumina and grow from there into the cell wall (Liese 1955). Wood decay fungi need water and oxygen for their metabolism. Water is also needed for the wood-degrading agents to reach the cell wall components. Due to the applied methods, there was not enough water for wood decay. From these aspects it becomes probable that the wood-decay fungi could not penetrate into the samples with oil-filled lumina and low moisture content and therefore could not decay the samples. However, the aim of our study was to test if the fungi can colonize/infect oil-treated wood. Practical use of essential oils is restricted to indoor use due to their high volatility and insufficient fixation. As application method the oils may be added to woods by brushing.

\section{CONCLUSIONS}

Our experiments showed that several plant essential oils are able to protect wood samples of a hardwood (Fagus orientalis) and softwood (Pinus taeda) against colonization by fungi.

The oils inhibited the growth of common moulds (Aspergillus niger, Penicillium commune, airborne spores) and important wood-decay fungi (Coniophora puteana, Trametes versicolor, Chaetomium globosum). Results indicated that lavender oil, lemon grass oil and thyme oil were the most effective oils against fungi. In view of wood decay it became obvious that at least the outer wood region is protected against deterioration if water and air are missing as a result of filling the wood cells with oil.

\section{ACKNOWLEDGEMENTS}

We thank the Gesellschaft der Förderer und Freunde des Zentrums Holzwirtschaft der Universität Hamburg for financial support.

\section{REFERENCES}

Blanchette, R.A. 2000. A review of microbial deterioration found in archaeological wood from different environments. International Biodeterioration \& Biodegradation 90: 93-98.

Boulogne, I.; Loranger-Merciris, G.; Ozier-Lafontaine, H.; Desfontaines, L.; Petit, P. 2012. Insecticidal and antifungal chemicals produced by plants: A review. Environmental Chemistry Letters 10: $325-347$.

Burt, S. 2004. Essential oils: their antibacterial properties and potential applications in foods - a review. International Journal of Food Microbiology 94: 223-253.

Caccioni, R.L.; Guizzardi, M.; Biondi, M.; Renda, A.; Ruberto, G. 1998. Relationship between volatile components of citrus fruit essential oils and antimicrobial action on Penicillium digitatum and Penicillium italicum. International Journal of Food Microbiology 43: 73-79. 
Carlton, R.R.; Gray, A.I.; Waterman, P.G. 1992. The antifungal activity of the leaf gland volatile oil of sweet gale (Myrica gale) (Myricaceae). Chemoecology 3: 55-59.

Chittenden, C.; Singh, T. 2011. Antifungal activity of essential oils against wood degrading fungi and their applications as wood preservatives. International Wood Products Journal 2:44-48.

Cojocariu, A.; Tanase, C. 2010. Macromycetes identified on the construction wood of historical monuments from Moldavia and causes of their development. Journal of Plant Development 17: 63-68.

Fatima, R.; Morrell, J.J. 2015. Ability of plant-derived oils to inhibit dampwood termite (Zootermopsis augusticollis) activity. Maderas-Cienc Tecnol 17(3): 685-690.

Fidah, A.; Salhi, N.; Rahouti, M.; Kabouchi, B.; Ziani, M.; Aberchane, M.; Famiri, A. 2016. Natural durability of Cedrus atlantica wood related to the bioactivity of its essential oil against wood decaying fungi. Maderas-Cienc Tecnol 18(4): 567-576.

French, R.C .1985. The bio-regulatory action of flavor compounds on fungal spores and other propagules. Annual Review Phytopathology 23: 173-199.

Goktas, O.; Ozen, E.; Baysal, E.; Mammadow, R.; Alma M.H . 2010. A research on the usage of extracts from two poisonous plants (Muscari neglectum Guss. and Gynandriris sisyrinchium (L.) Parl.) as a wood preservative. Wood Research 55: 53-62.

Isman, M.B.; Miresmaill, S.; MacHial, C. 2011. Commercial opportunities for pesticides based on plant essential oils in agriculture, industry and consumer products. Phytochemistry Reviews 10: 197-204.

Liese, W. 1955. On the decomposition of the cell wall by micro-organisms. Rec $B r$ Wood Preservative Association 159-160.

Mahmoud, A.LE. 1994. Antifungal action and antiaflatoxigenic properties of some essential oil constituents. Letters in Applied Microbiology 19: 110-113.

Ortiz, R.; Parraga, M.; Navarrete, J.; Carrasco, I.; de la Vega, E.; Ortiz, M.; Herrera, P.; Jurgens, J.A.; Held, B.W.; Blanchette, R.A. 2014. Investigations of biodeterioration by fungi in historic wooden churches of Chiloé, Chile. Microbial Ecology 67: 568-575.

Pánek, M.; Reinprecht, L.; Hulla, M. 2014. Ten essential oils for beech wood protection. Efficacy against wood-destroying fungi and moulds, and effect on wood discoloration. BioResources 9: 55885603.

Sailer, M. 2001. Anwendung von Pflanzenölimprägnierungen zum Schutz von Holz im Außenbereich. PhD thesis, University of Hamburg, 164 pp.

Schmidt, O. 2006. Wood and tree fungi. Biology, damage, protection, and use. Springer-Verlag, Berlin, Heidelberg, 334 pp.

Singh, T.; Singh, A. 2012. A review on natural products as wood protectant. Wood Science Technology 46: 851-870

Sterflinger, K .2010. Fungi: their role in deterioration of cultural heritage. Fungal Biology Reviews 24: 47-55.

Su, Y.C.; Ho, C.L.; Wang, E.I.C.; Chang, S.T. 2006. Antifungal activities and chemical compositions of essential oils from leaves of four eucalypts. Taiwan Journal of Forestr Science 21: 49-61. 
Viuda-Martos, M.; Ruiz-Navajas, Y.; Fernandez-Lopez, J.; Perez-Alvarez, J. 2008. Antifungal activity of lemon (Citrus lemon L.), mandarin (Citrus reticulata L.), grapefruit (Citrus paradisi L.) and orange (Citrus sinensis L.) essential oils. Food Control 19: 1130-1138.

Voda, K.; Boh, B.; Vrtacnik, M.; Pohleven, F. 2003. Effect of the antifungal activity of oxygenated aromatic essential oil compounds on the white-rot Trametes versicolor and the brown-rot Coniophora puteana. International biodeterioration biodegradation 51: 51-59.

Wang, S-Y.; Chen, P-F.; Chang, S-T. 2005. Antifungal activities of essential oils and their constituents from indigenous cinnamon (Cinnamomum osmophloeum) leaves against wood decay fungi. Bioresource Technology 96: 813-818.

Wong, S.Y.Y.; Grant, R.I.; Friedman, M.; Elliott, C.; Situ, C. 2008. Antibacterial activities of naturally occurring compounds against Mycobacterium avium subsp. paratuberculosis. Applied Environmental Microbiology 74: 5986-5990.

Yang, V.W.; Clausen, C.A. 2006. Moldicidal properties of seven essential oils. International Research Group on Wood Protection 06-30404.

Yang, V.W.; Clausen, C.A. 2007. Antifungal effect of essential oils on southern yellow pine. International Biodeterioration \& Biodegradation 59: 302-306

Zyani, M.; Mortabit, D.; El Abed, S.; Remmal, A., Koraichi, S.I. 2011. Antifungal activity of five plant essential oils against wood decay fungi isolated from an old house at the Medina of Fez. International Research Journal of Microbiology 2: 104-108. 